DOI https://doi.org/10.18551/rjoas.2020-09.02

\title{
THE ENVIRONMENTAL COMMUNICATION BASED ON LOCAL WISDOM: A CASE STUDY ON WATER CONSERVATION OF RIMBANG BALING WILDLIFE RESERVE
}

\author{
Nurdin*, Sukartik Dewi, Usman, Badri Muhammad \\ Faculty of Da'wah and Communication, Universitas Islam Negeri Sultan Syarif Kasim Riau, \\ Pekanbaru, Indonesia \\ *E-mail: nurdin@uin-suska.ac.id
}

\begin{abstract}
This study aims to determine environmental communication based on local wisdom toward water resources conservation activities at Rimbang Baling Wildlife Reserve, Riau Province, Indonesia. The data collection was conducted by interviewing the parties involved in water resource conservation consisting of community leaders, empowerment organizations, and local communities. This study found that environmental communication based on local wisdom with four strategies, namely: (1) Message through Lubuk Larangan with cultural and conservation values approach; (2) Message through Hutan Larangan to maintain water buffer zones sustainable; (3) Message through empowerment to support community development activities through socio-economic activities, village institutions, and community radio; (4) Messages through da'wah activities conducted by the ulama conservation forum and the mysticism community.
\end{abstract}

\section{KEY WORDS}

Environmental communication, water conservation, local wisdom, Rimbang Baling.

The majority of preservation guided by local wisdom has been done in Indonesia, one of them is at Rimbang Baling Wildlife Reserve, with its official name Suaka Margasatwa Bukit Rimbang Bukit Baling (SMBRBB). SMBRBB is upstream of two large rivers, namely the Subayang River and the Singingi River. As administrative, SMBRBB is located in Kampar and Kuantan Singingi, Riau Province, Indonesia. This area is in the form of hilly forests as life support, regulates water systems, supplies oxygen, and habitats for rare flora and fauna. In this area, there is a freshwater laboratory owned by WWF to maintain water quality.

Water conservation needs to be done because damage to water resources can lead to land degradation and soil erosion (Puno \& Puno, 2019). The SMBRBB area is known as a natural water source, which is still preserved well compared to other places. This is because of the main role of local communities in maintaining conservation through local wisdom. The study of Mauro \& Hardison (1999) confirms that indigenous peoples and local communities play an important role in biodiversity management. Ince (2018) explains that environmental conservation must use resources efficiently and effectively from macro to micro levels with a systematic approach.

Although the community has local wisdom, the influence from the outside communities, especially from actors who provide economic benefits has the potential to reduce the social capital of the community. The study of YASA \& WWF (2005) mentions that the company's presence can give hope for the community, but the views from there are socio-cultural aspects of indigenous exploitation, and abuse of the concept of communal customary to provide the right communal to another party.

An example of local wisdom that is still preserved in the SMBRBB area is the prohibition pool (Called Lubuk Larangan), which is a part of the river that is wider and deeper (has a niche) and is a place for fish to breed. Taking fish here is prohibited for a particular period of time according to the agreement of the community. Due to Lubuk Larangan, local communities develop the concept of river management, from open access resources to communally owned resources. The changes in concept can reduce the overexploitation of natural resources (Rahmadina et al ., 2016). 
Local wisdom is local ideas that are wise, full of wisdom, and have values that embedded and followed by the community. In the anthropological concept, local wisdom is known as indigenous or local knowledge or local genius that has the basis of cultural identity. The community develops the local knowledge and technology system in order to solve problems in life, such as conservation, food, and health (Makmur, 2011). The improvement of local and indigenous communities' knowledge is important to the source of climate knowledge and adaptation strategies (Nakashima et al., 2012). This local wisdom is getting stronger with the existence of custom-based indigenous institutions that have a more powerful influence than government and religion (Eko et al., 2014).

Conservation of water resources is prominent local wisdom in the SMBRBB area. The conservation of water resources is intended to maintain the sustainability and existence of water resources, including support, capacity, and function (Kementerian Pekerjaan Umum, 2017). Water conservation is a comprehensive effort to maintain, conserve water, water resources, related ecosystem environment also efforts to save consumption as efforts to solve related problems (Sarminingsih, 2008). The use of water that is not wise has an effect on the damage of the water resources ecosystem and increases pollution, also threatening the availability of water resources (Soenyoto, 2013).

The message of water resources conservation was conveyed by community leaders in the SMBRBB area from generation to generation. The message is the main element of communication, apart from the source, receiver, and channel. Communication cannot occur without messages being exchanged. Pearson et al. (2011) define communication as the process of using messages to generate meaning. According to Beebe et al. (2011) communication is effective if it meets three criteria: the message conveyed is understood, the message conveyed can achieve the desired effect, and the message conveyed is relevant with communication ethics.

Many studies have been conducted at SMBRBB. However, only a few of them have studied environmental communication in the context of water resources conservation. Suandy et al. (2014) raised the issue of environmental degradation at the SMBRBB buffer zone. The high demand of the community to fulfill their daily needs and improve the economy around the buffer zone of the SMBRBB is always related to the plantation land area they have. Sinamo (2016) find that WWF as the most active partner of BBKSDA Riau in helping the SMBRBB management. BBKSDA Riau working with WWF to disseminate to the public, handling of illegal logging, and implement micro-hydro or fresh-water project.

This study explores the communication and social dimensions of the SMBRBB community about environmental conservation, especially water sources in the upper reaches of the Subayang River. This theme was chosen because the local wisdom of the local community is still well preserved. The local wisdom of the local community is heavily influenced by traditional and Islamic values, which are one of the characteristics of the local wisdom of the Malay community in Riau. This study aims to determine environmental communication based on local wisdom on water resources conservation activities at Rimbang Baling Wildlife Reserve, Riau Province, Indonesia.

\section{METHODS OF RESEARCH}

This study uses a constructivist paradigm with a qualitative approach. Data collection was conducted by interviewing partied who involve in water resources conservation actors and Focus Group Discussions (FGD) with stakeholders at the study location. This study was conducted in Tanjungbelit Village, Kampar Regency, Riau Province. This location was chosen because it is the center of water resources conservation activities involving empowerment organizations. The study was carried out in stages in 2018 and 2019. The study informants consisted of communication actors representing community leaders (Called Ninik Mamak), empowerment organizations (IMBAU and WWF), and local communities. 


\section{RESULTS AND DISCUSSION}

Message on Water Conservation through Lubuk Larangan. Lubuk Larangan or prohibition pool in the form of wisdom that develops in local communities in utilizing river water fishery resources. Lubuk Larangan is a manifestation of the principle of conservation conducted by the community towards river water fishery resources (Yuliaty \& Priyatna, 2014). Lubuk is a large and deep overdraft in the river flow. Lubuk is usually inhabited by fish because the water is calm and there are lots of shrubs so that it becomes a suitable place for fish breeding.

The Subayang River, which has a swift flow of water, has many deep and calm waterfalls. In the past, people used to look for fishes in lubuk so that over time the fish supply in the area decreased. Moreover, many immigrants also look for fish in the Subayang River. Based on this condition, community leaders who were in the Subayang River area then made local wisdom called Lubuk Larangan. The concept of Lubuk Larangan is to prohibit people from taking fish in lubuk that have been marked or restricted by local traditional leaders. The procession of closing and opening Lubuk Larangan involves a traditional ceremony led by traditional leaders.

Tanjung Belit Village has two Lubuk Larangan that only open once a year at low tide. When Lubuk Larangan is closing, people are prohibited from fishing in the Lubuk Larangan area no matter what. The objective of this action is the fish can reproduce and grow better. Therefore, in harvest time, the results are abundant and can be used by the community. At the time of harvesting fish, the customary leader will catch fish early, then the other communities will follow him.

Environmental communication through Lubuk Larangan is conveyed by Ninik Mamak to the community. The strategy is conveyed through interpersonal and group channels, especially in customary forums. The conservation message is effective in influencing the community not to disturb Lubuk Larangan before harvest time. It is due to apart from containing conservation narratives, the message prohibiting damaging water resources contains magical and transcendental narratives. This research informant said:

"Tak ada satu pun warga masyarakat yang berani mengambil ikan di Lubuk Larangan yang sudah ditetapkan oleh pemangku adat dan masyarakat, sampai waktu yang ditentukan untuk dibuka (No one dares to take fish in Lubuk Larangan that had been set by the customary and community leaders until the time it was set for harvest)."

In addition, the other informants said that culturally the community preserves the river because most of them still use the river for bathing, cooking, and washing. The preservation of Subayang River has happened because people are afraid to have activities that violate customs. One of the messages in customary sanctions is: whoever destroys the river will be excluded.

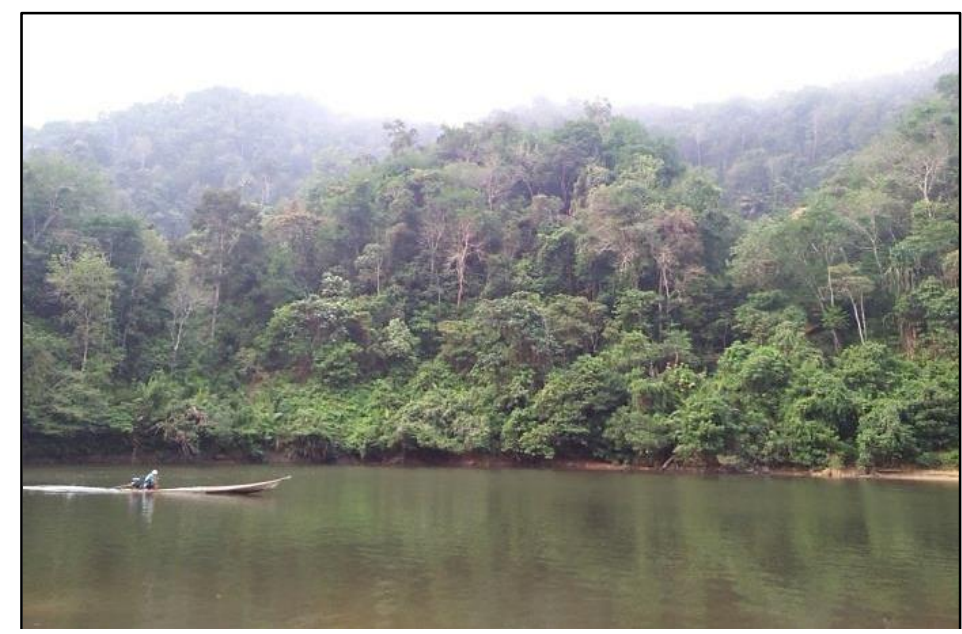

Figure 1 - Hutan Larangan area at the research location 
Message on Water Conservation through Hutan Larangan. The community in the study location owns the prohibition forest (Called Hutan Larangan) area as a buffer for the village environment and water sources in the area. In this area, there is ecotourism of Batu Dinding Waterfall that merge as one village. The source of the waterfall comes from a spring in the forest. The community realizes that in order to be sustainable as a buffer to life, it must be maintained. Therefore, the village government together with traditional leaders agreed on the prohibition forest covering an area of 300 hectares that cannot be use and destroyed.

Hutan Larangan is a forest area that is prohibited from being cut down by the community. Logging may only be limited for certain purposes, such as building houses or public facilities and with the permission of Ninik Mamak and the Village Head. The existence of Hutan Larangan makes the landscape green because of the preservation of biodiversity. The existence of Hutan Larangan is also a fortress for water sources and maintains the robustness of the other hills that are abundant around it.

Hutan Larangan is owned by each tribe that lives in the village. The message to protect the Hutan Larangan is conveyed by each tribe or opinion leader to their followers. Thus, all tribes have a commitment to local wisdom to protect forests in order to remain sustainable. Based on observation, the various types of tropical trees live in Hutan Larangan has been founded. The forest is also a habitat for wildlife so that the area's ecosystem remains natural. This natural harmony is not only beneficial for the ecosystem but also for people's lives.

Message on Water Conservation through Community Empowerment. Water resources conservation activities are conducted by the community together with the IMBAU Consortium consisting of the World Wildlife Fund (WWF), Indonesia Ecotourism Network (INDECON), and Yayasan Pemberdayaan Masyarakat dan Pendidikan Konservasi Alam (YAPEKA). The IMBAU Consortium conducted systematic community development activities. At first, they conducted a mapping to understand the potential of the community and see environmental problems. Furthermore, they are intensively communicating in community forum, invites the community to collaborate in developing village potential and sustainable economy. This communication and collaboration can improve public awareness to utilize and conserve natural resources in a sustainable manner. In order to support ecotourism activities, IMBAU empowers the community to open homestay services. When the study was conducted, there were six houses belonging to the homestay group. Through many alternative economic activities, people are more concerned about natural resources and the environment in their villages. This research informant said:

"Awal kita masuk memang sulit, banyak penolakan dan ancaman. Masyarakat curiga kita akan menjual hutan mereka kepada pihak asing. Tapi melalui pendekatan persuasif dan kegiatan bersama akhirnya mereka sadar tentang pentingnya menjaga lingkungan, terutama hutan dan sungai. Saat ini masyarakat sangat mendukung kegiatan-kegiatan kita (At first, it was difficult, there were many rejections and threats. The people are suspicious that we will sell their forests to foreigners. By persuasive approach and joint activities, they finally realized the importance of protecting the environment, especially forests and rivers. Nowadays, the community is supporting our activities)."

In order to facilitate empowerment activities, IMBAU established a communication forum called Forum Masyarakat Batang Subayang dan Sungai Bio, consisting of representatives from Ninik Mamak, village heads, youth, indigenous peoples, and so on. The communication forums are to strengthen local wisdom as an effort to protect the Rimbang Baling areas. This forum is to do coordination and information sharing between the community and stakeholders.

Communication activities are also conducted through the communication media of the Lintas Subayang Community Radio 107.7 FM. The community radio usually delivers messages of environmental preservation to the community, in the form of information, teachings of local wisdom, and advice from local elders. The Lintas Subayang Community Radio is one of the community radios that functions to inform conservation messages. Moreover, community radio also functions as the source of public information.

Message on Water Conservation through Da'wah Activities. Da'wah activities play an important role in the conservation of water resources in the study location. Based on the 
results of the FGD conducted by the study team with the village community and WWF, it was revealed that the preservation of existing water resources along the Subayang River was supported by the existence of the Conservation Proselytizer Communication Forum (Called Forkodas) formed by WWF. This forum contains local religious leaders who often conduct religious lectures.

Forkodas initiated messages on water resources conservation through persuasive da'wah activities. Forkodas has received guidance so that the preachers can provide conservation materials for Friday sermons, village recitations, and recitation for mothers. Forkodas previously received assistance from Majelis Ulama Indonesian (MUI) Riau chapter. MUI has been released Fatwa No. 04 of 2014 on endangered species conservation to maintain the balance of the ecosystem.

Besides formal conservation da'wah activities, there is also mysticism (local language: Suluk) in the study location. Suluk not related to the existence of "preserving nature" directly, but through transcendental communication of followers personally to God. Suluk strengthen faith with remembrance, how to prepare death, and so on. Through Suluk activities, followers will live in asceticism, so they are prohibited from doing bad things to other people and the environment.

Water Conservation for Ecological Sustainability. Ecological sustainability is an important issue in sustainable development, including at the village level. According to Keraf (2010b), the paradigm of sustainable ecology is a fundamental change in national policies that prioritize life preservation to achieve ecological sustainability. The main idea is not only development but maintaining and preserving the ecology and everything inside them.

This ecological sustainability paradigm is a criticism of the weaknesses of a sustainable development paradigm that tends to be anthropocentric, considering nature to be merely a tool to meet human needs. This paradigm rests on the ideology of materialism which is not critically tested but is taken for granted (Keraf, 2010a). The concept of ecological sustainability practiced at the SMBRBB is in relevant with the 2015-2030 Sustainable Development Goals (SDGs), especially in the aspect of climate change, manage forests sustainably, land change, stop and rehabilitate land degradation, and stop the extinction of biodiversity (BPS, 2014; SDSN, 2015).

The message of water resource conservation as the main issue of ecological sustainability at the Rimbang Baling Wildlife Reserve is conducted by developing communications. Communication makes the development interventions more populist, and more sensible to the local context (Inagaki, 2007). Communicating about the message of water resources ecological sustainability will improve understanding of environmental ethics, the moral norms, and rules that govern human behavior with nature (Keraf, 2010a). The communication conducted by IMBAU and WWF with the community was able to encourage the community to conserve the water resources of the Subayang River.

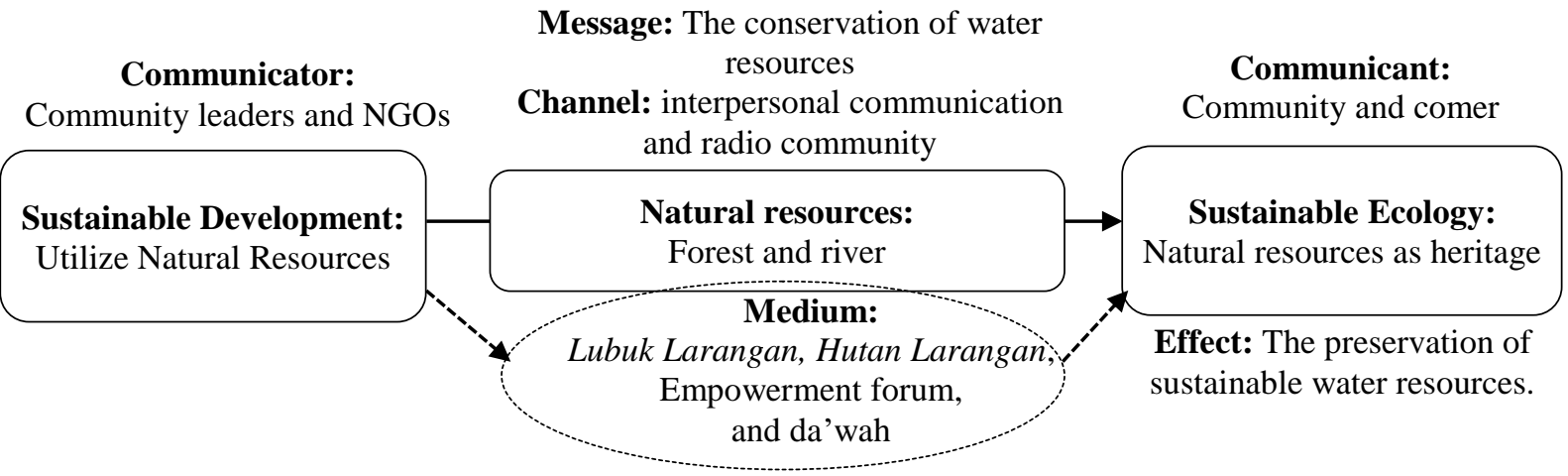

Figure 2 - The environmental communication for ecological sustainability

The main parties as communicators of water resources conservation messages at Rimbang Baling Wildlife Reserve are community leaders (Ninik Mamak, religious leaders, youth leaders, and village government leaders) and non-governmental organizations (NGOs) 
such as IMBAU and WWF. These main parties intensively communicate conservation messages through interpersonal communication channels and community radio. The communication medium to communicate message are Lubuk Larangan, Hutan Larangan, empowerment forums, and village institutions. Through this medium, communication is carried out interpersonal with the support of community radio. The recipients of this message are a community in the Rimbang Baling Wildlife Reserve area and comers, both with economic and recreational interests. The impact to be achieved from this conservation message is the preservation and preservation of water resources in Rimbang Baling Wildlife Reserve, especially the Subayang River.

The practice of conserving water resources at SMBRBB can be used as material for the development of natural resource management in Indonesia. In this context, what needs to be considered according to Yuliaty \& Priyatna (2014) are: (1) Improving Lubuk Larangan management or other resource management practices so that they do not only have the spirit to manage; (2) The management of existing resources in one community cannot be automatically implemented in other communities. Improving resource management by enrichment and renewal of local knowledge needs to be done without forgetting the dynamics of knowledge to create sustainable resource management.

\section{CONCLUSION}

Environmental communication based on local wisdom in water resources conservation is conducted by four communication ways. Firstly, Lubuk Larangan has been created to limit the use of rivers as a source of livelihood for the fisheries sector. Secondly, Hutan Larangan has been created to suppress illegal logging practices and uncontrolled logging so that they have a sustainable water buffer area. Thirdly, community empowerment for sustainable economic activities so that people do not damage the environment. Fourthly, a conservation da'wah forum has been created to convey conservation messages through religious activities. The four communication ways run simultaneously and have a correlation with each other. The success of conservation communication in Rimbang Baling Wildlife Reserve is not only influenced by wisdom but also influenced by belief and religious values. However, the influence of local wisdom is stronger than religious values.

\section{REFERENCES}

1. Beebe, S.A., Beebe, S.J., \& Ivy, D.K. (2011). Communication: Principles for A Lifetime. Fourth Edition. Boston (US): Allyn \& Bacon.

2. BPS [Badan Pusat Statistik]. (2014). Kajian Indikator Sustainable Development Goals (SDGs). Jakarta: Badan Pusat Statistik.

3. Eko, S., Khasanah, T.I., Widuri, D., Handayani, S., Handayani, N., Qomariyah, P., Aksa, S., Hastowiyono, Suharyanto, \& Kurniawa, B. (2014). Desa Membangun Indonesia. Yogyakarta: Forum Pengembangan Pembaharuan Desa (FPPD).

4. Inagaki, N. (2007). Communicating the Impact of Communication for Development: Recent Trends in Empirical Research. Washington DC: The World Bank.

5. Ince, F., (2018). Perceptions of environmental sustainability amongst mineworkers. Global. J. Environ. Sci. Manage., 4(1): 1-8. Doi: 10.22034/gjesm.2018.04.01.001.

6. Kementerian Pekerjaan Umum. (2017). Modul Konservasi Sumber Daya Air Pelatihan Dasar Teknis Bidang SDA. Jakarta: Pusat Pendidikan dan Pelatihan Sumber Daya Air dan Konstruksi Kementerian Pekerjaan Umum.

7. Keraf, A.S. (2010a). Etika Lingkungan Hidup. Jakarta: Kompas.

8. Keraf, A.S. (2010b). Krisis dan Bencana Lingkungan Hidup Global. Yogyakarta: Kanisius.

9. Makmur, A (Ed). 2011. Kearifan Lokal di Tengah Modernisasi. Jakarta: Kementerian Kebudayaan dan Pariwisata Republik Indonesi.

10. Mauro, F., \& Hardison, P.D. (1999). Traditional Knowledge of Indigenous and Local Communities: International Debate and Policy. Ecological Applications 10 (5): 12631269. 
11. Nakashima, D.J., Galloway McLean, K., Thulstrup, H.D., Ramos Castillo, A. \& Rubis, J.T. (2012). Weathering Uncertainty: Traditional Knowledge for Climate Change Assessment and Adaptation. Paris: UNESCO and UNU.

12. Puno, G.R., \& Puno, R.C.C. (2019). Watershed conservation prioritization using geomorphometric and land use, land cover parameters. Global J. Environ. Sci. Manage., 5(3): 279-294. Doi: 10.22034/gjesm.2019.03.02.

13. Rahmadina, A.H., Rachma, N.P., \& Mangunjaya, F.M. (2016). Studi Lubuk Larangan di Bentang Alam Bukit Rimbang Bukit Baling Riau. Di dalam: Mangunjaya et.al. (eds). Studi Kekayaan Hayati Kawasan Bentang Alam Rimbang Baling, Riau. Prosiding Seminar Hasil Kuliah Kerja Lapangan (KKL) Fakultas Biologi Universitas Nasional, Sabtu, 4 Juni 2016.

14. Sarminingsih, A. (2008). Kajian Upaya Konservasi Sumber Daya Air dalam Peningkatan Kesadaran Masyarakat. Jurnal Presipitasi 5 (2): 42-48. Doi: 10.14710/presipitasi.v5i2.4248.

15. Sinamo, N.I. (2016). Keterlibatan World Wildlife Fund For Nature (WWF) dalam Upaya Konservasi Harimau Sumatera di Suaka Margasatwa Bukit Rimbang Bukit Baling Provinsi Riau Tahun 2010-2014. JOM FISIP 3 (1): 1-13.

16. Soenyoto, S. (2013). Konservasi dan Pelestarian Sumber Daya Air di Indonesia. BENTANG 1 (1): 52-61.

17. Suandy, I., Mulyadi, A., Moersidik, S.S., \& Suganda, E. (2014). Degradasi Lingkungan di Kawasan Penyangga Suaka Margasatwa Bukit Rimbang Bukit Baling Propinsi Riau. Jurnal Ilmu Lingkungan 8 (2): 214-223.

18. SDSN [Sustainable Development Solutions Network]. 2015. Getting Started with the Sustainable Development Goals. Retrieved from: http://unsdsn.org/wpcontent/uploads/2015/12/151211-getting-started-guide-FINAL-PDF-.pdf.

19. YASA \& WWF. (2005). Laporan Akhir Kondisi dan Kajian Koridor Taman Nasional Bukit Tigapuluh Suaka Margasatwa Bukit Rimbang Bukit Baling. Pekanbaru: Yayasan Alam Sumatera dan Yayasan WWF Indonesia.

20. Yuliaty, C. \& Priyatna, F.N. (2014). Lubuk Larangan: Dinamika Pengetahuan Lokal Masyarakat dalam Pengelolaan Sumber Daya Perikanan Perairan Sungai di Kabupaten Lima Puluh Kota. J. Sosek KP 9 (1): 115-125. 